\title{
Relationship Between Spiritual Well-being with Resilience and Mental Health in Social Conflict Victims in Aceh Singkil
}

\author{
Raja Oloan Tumanggor ${ }^{1}$, Agoes Dariyo $^{2}$ \\ Faculty of Psychology - Universitas Tarumanagara Jakarta \\ Email: ${ }^{1}$ rajat@fpsi.untar.ac.id, ${ }^{2}$ agoesd@fpsi.untar.ac.id
}

\begin{abstract}
Communities who are victims of social conflicts feel the bitter experience that their houses have been forcibly demolished, torn down and even burned to the ground. However, they must keep their religious teachings by worshiping regularly. Because the condition of worship place has been destroyed, then now they have difficulty to worship well. This study wanted to know the relationship between spiritual well-being with resilience and mental health to victims of social conflict in Aceh Singkil. Data collection was using measuring instruments of spiritual well-being questionnaires, resilience and mental health. The number of subjects in this study was 55 people. Analysis of data was using multiple correlation. The results show that there is a significant relationship between spiritual well-being and resilience, there is a significant relationship between spiritual well-being and mental health, there is a significant relationship between resilience and mental health.
\end{abstract}

Key Word: spiritual well being, resilience, mental health, and victims of social conflict.

\section{INTRODUCTION}

Victims of the social conflicts experienced prolonged psychological trauma, because they could not forget the bad experiences of their past. They have seen the peak of social conflict between them and other societies. They witnessed the burning of worship houses by the other group of people. They are not natives of the area, but are imported from outside the area coordinated neatly and systematically.

The government was unable to withstand the attitudes and actions carried out by the group. Although they are on the alert, they could not do anything, because the anti-tolerant group is very daring and could not be prevented. As a result, within a short time there was an act of burning houses of worship.

Today, the societies of the victims of social conflict must live their daily activities, with no place for worship. They are not allowed to rebuild the place of worship, because they are prohibited by the local government. Although they have filed official permits repeatedly, the license has never been issued by the government. Therefore, they worship at the burnt-out place of their worship house.

Social conflict occurs because of differences between two or more parties that can not be resolved properly, so the situation becomes tense and causes social upheaval in society (Suharko, 2016; Pruitt and Rubin, 2009). Suharko's view (2016) justifies the conditions that occur in some communities in Aceh Singkil. They are victims of the social conflict, and now they are still experiencing psychological trauma.

The only thing that they can do, is to develop a spiritual life that has been entrenched in their life. They believe that they can feel peace and quiet when they are serious to live their worship. They believe that their spiritual welfare is tested through the conditions experienced today. Although they face a difficult situation, they still survive and maintain their spiritual life as well as possible. 
Apparently they realize that diligently performing worship activities will bring resilience in their life. They are even stronger, steadfast, and not easily give up under any difficult conditions. Difficult conditions will encourage them to develop a strong character. They must have the fortitude and remain optimistic that they are able to deal with difficult situations.

Communities who are victims of social conflicts are also aware that difficult situations indirectly also train for healthy mental development in their lives. A difficult situation will develop a resilience personality. Resilient people are people who keep thinking positive and optimistic that they are able to deal with and solve difficulty in their life well. Resilient people are people who remain calm, have a selfcontrol and able to fit in a good social environment (Smith et al., 2013). So a resilient person is a person who has a healthy mental as well.

\section{METHODS}

Characteristics of the subject

The study involved 55 people ( 31 women and 24 men), tribe Pak-pak Dairi Batak, living in Aceh Singkil, Nanggroe Aceh Darussalam. The average age of the subject is 40.8 years, with standard deviation $=$ 18.46453 .

Research instruments

Data were collected using a spiritual well-being questionnaire (alpha chronbach $=.883$ ), resilience questionnaire (alpha chronbach $=.922)$ and mental health questionnaire (alpha chronbach $=.928)$.

Analytical techniques

The collected data is analyzed using multiple correlation. Before performing the correlation test, normality and linearity tests were performed.

\section{RESULTS}

Assay test results

Below is the result of normality test. All data of research variable are normal (table 1). Meanwhile, through the linearity test, all data is not linear (table 2).

Table 1. Normality test results

\begin{tabular}{lllll}
\hline & Variable & P & Sign & Meaning \\
\hline 1 & Spiritual Well-Being & .318 & $\mathrm{p}>.05$ & Normal \\
2 & Resilience & .239 & $\mathrm{p}>.05$ & Normal \\
3 & Mental health & .053 & $\mathrm{p}>.05$ & Normal \\
\hline
\end{tabular}

Table 2. Linearity test results

\begin{tabular}{lllll}
\hline & Variable & $\mathrm{p}$ & Sign & Meaning \\
\hline 1 & $\begin{array}{l}\text { Spiritual Well-Being }- \\
\text { resilience }\end{array}$ & $\mathrm{P}=.001$ & $\mathrm{P}<.05$ & Nonlinear \\
2 & $\begin{array}{l}\text { Resilience -Mental health } \\
\mathrm{P}=.024\end{array}$ & $\mathrm{P}<.05$ & Nonlinear
\end{tabular}

International Seminar on Psychology 2017, August 12th 2017 Individual and Multi cultural Social Empowerment for Achieving Social Harmony $\mid 38$ 


\begin{tabular}{|c|c|c|c|c|}
\hline 3 & $\begin{array}{l}\text { Spiritual well-being - Mental } \\
\text { health }\end{array}$ & $\mathrm{P}=.019$ & $\mathrm{P}<.05$ & Nonlinear \\
\hline
\end{tabular}

Therefore, because of the unfulfilled assumption test, then the data were tested by using the test of correlation. The correlation test results are known as follows (table 3 ).

Table 3. Correlation results

\begin{tabular}{llccc}
\hline \multicolumn{1}{c}{ Correlation } & r & \multicolumn{1}{c}{$\mathbf{p}$} & \multicolumn{1}{c}{ Meaning } \\
\hline 1 & $\begin{array}{l}\text { Spiritual Well-Being - } \\
\text { Resilience }\end{array}$ & $.458(* *)$ & $\mathrm{p}=.000 ; \mathrm{p}<.01$ & Very significant \\
2 & $\begin{array}{l}\text { Spiritual Well-Being- } \\
\text { Mental health }\end{array}$ & $.448(* *)$ & $\mathrm{p}=.000 ; \mathrm{p}<.01$ & Very significant \\
3 & Resilience - Mental health & $.500(* *)$ & $\mathrm{p}=.000 ; \mathrm{p}<.01$ & Very significant \\
\hline
\end{tabular}

\section{DISCUSSION}

The results of the correlation test show that there is a significant relationship between spiritual well-being with resilience. Spiritual well-being is a source of spiritual happiness that will radiate a positive attitude for everyone. A person has a positive understanding and appreciation of the values of religious teachings in his life. He applied every value of religious teachings to address every problem of his life. The values of the teachings of religion give enlighten thoughts, feelings, attitudes and actions every day. When having a difficult problem, someone who has a spiritual well-being will develop a positive attitude, and ultimately makes his life feel happy (Kim et al., 2013). So a spiritual well-being will make a person able to achieve the happiness of life (Dariyo \& Tumanggor, 2016; Etemadifar et al., 2016; Rowold, 2011). Problems are not a threat that will interfere with his life. A difficult problem is viewed as a challenge that must be dealt with as well as possible.

With a spiritual well-being, one will develop resilience in life, because the values of religious teachings require everyone to be strong, tough, and steadfast in facing every issue of his life (Kim et al., 2013). He is brave and confident in addressing every issue of his life. He feels optimistic that every problem of life can be overcome with his well-being. He will not give up, let alone despair in the face of his life problems. He remains focused and continues to solve the problem of his life. Thus, the spiritual well-being is closely related to resilience in everyone.

In this study, it was also found that there is a significant relationship between spiritual wellbeing and mental health (Jafari et al., 2010). One of the characteristics of people who have a good spiritual-well being is characterized by positive thinking. Positive thinking is the ability of a person to see the positive side of every problem in his life. Every problem has a positive impact on everyone, if the problem is viewed positively. The problem of life is considered as a tool that is the problem that will trigger and spur a person's motivation to optimize every potential in his life. With the problem of life, then someone is challenged to think creatively in solving the problem of his life. In the humanistic view, the problem of life will spur someone to actualize their full potentials as well as possible. This is what indicates a healthy mental condition.

In addition, there was found a significant relationship between resilience and mental health. Resilience as a personal characteristic is tough, strong and steadfast in the face of every difficulty in life. The resilient is a person who is really strong and steadfast even though he has a life issue. He does not complain about his problems, but he tries to find the best way to solve it (Falentina and Dariyo, 2016). 


\section{CONCLUSION}

It is concluded that there is a significant relationship between spiritual-well being with resilience, there is a relationship between spiritual well-being with mental health, and there is a significant relationship between resilience and mental health.

\section{Note:}

Thanks to the Department of Higher Education, Research and Technology of Republic of Indonesia that has supported this research activity, so it can be implemented well.

\section{BIBLIOGRAPHY}

Dariyo, A., \& Tumanggor, R.O. (2016). Upaya mencegah perceraian: Peran Spiritual Well-being dan Kematangan Emosi terhadap Kepuasan Perkawinan. Laporan Penelitian, tidak diterbitkan. Jakarta: Universitas Tarumanagara.

Etemadifar, S., Hosseiny, R.S., Zikari, A., Omrani, A., \& Alijanpoor, M. (2016). The Relationship Between Spiritual Well-being and Life Satisfaction in Females with Infertility. Women's Health Bulletin October 3 (4): e32344.

Falentina, M., \& Dariyo, A. (2016). Gambaran Resiliensi pada Ibu yang Memiliki Anak Thalassemia. Journal An-Nafs, Kajian Penelitian Psikologi, 1 (1), 15-30.

Jafari, E., Dehshiri, G.Z., Eskandari, H., Najafi, M., Heshmati, R., \& Hoseinifar, J. (2010). Spiritual Wellbeing and Mental Health in University Students. Procedia Social and Behavioral Sciences 5, $1477-1481$.

Kim, S., Miles-Mason, E., Kim, C.Y., \& Esquivel,G.B. (2013). Religiosity/Spirituality and Life Satisfaction in Korean American Adolescents. Psychology of Religious and Spirituality, 5 (1), 33 40 .

Pruitt, G.P., \& Rubin, J.Z. (2009). Teori Konflik Sosial, Yogyakarta: Pustaka Pelajar.

Rowold, J. (2011). Effects of Spiritual Well-being on Subsequent Happiness, Psychological Well-being, and Stress. Journal of Religious Health 50: 950-963.

Smith, L., Webber, R., \& DeFrain, J. (2013). Spiritual Well-being and Its Relationship to Resilience in Young People: A Mixed Methods Case Study. SAGE Open April - June 2013: 1-16.

Suharko (2016). Masyarakat Adat versus Korporasi: Konflik Sosial Rencana Pembangunan Pabrik Semen di Kabupaten Pati Jawa Tengah Periode 2013-2016. Jurnal Ilmu Sosial dan Ilmu Politik, 20 (2), 97-116. 